\title{
A Bibliometric Analysis of the Top 100 Most-Cited Articles in Chemotherapy (1910- 2019)
}

\author{
Mohammad FaisalUddin ${ }^{1}$, Pulwasha Maria Iftikhar ${ }^{2 *}$, Roopam Bansal ${ }^{3}$, Azadeh Khayat ${ }^{1}$, Azeem Husain \\ Arastu ${ }^{1}$, Javidulla Khan ${ }^{1}$ and Jain Akriti ${ }^{4}$
}

${ }^{1}$ Department of Medicine, Deccan College of Medical Science, India

${ }^{2}$ Department of Health Sciences, St John's University, Queens, USA

${ }^{3}$ Department Of Medicine, Sagar Gian Medical College, India

${ }^{4}$ Florida hospital, Orlando, USA

Submission: October 29, 2019; Published: December 06, 2019

"Correspondence Author: Iftikhar Pulwasha Maria, Department of Health Sciences, St John's University, Queens, New York, USA

\begin{abstract}
Background: Chemotherapy is the foundation for the treatment of various cancers. The advent of targeted treatment and chemotherapy has excited clinicians and scientists to perform clinical trials and studies. With limited medical care resources, bibliometric studies can help guide both researchers and research funding organizations to reallocate and increase the research activity.

Objective: To identify, characterize and review the 100 most-cited articles in the field of chemotherapy focusing on papers that modified therapeutic concepts and influenced the oncologist's decision making.

Methods: Two independent researchers, Iftikhar PM, Uddin MF explored the databases of Scopus, Web of Science and Google Scholar with truncated search term "chemotherapy" to extract articles between 1910 and Aug 2019. After an extensive search, all the retrieved articles were sorted according to the number of citations. After that, they were manually refined and normalized to unify terms and to remove typographical, transcription or indexing errors. A detailed analysis was carried out to identify trends and reveal significant discriminators. For each article, the number of citations, year of publication, journal, first and senior author, journal name and country of origin of the authors and articles focusing on specific malignancy were studied.

Results: The number of citations for the top 100 chemotherapy articles ranged from 1675 to 8830 with a median of 2324 citations. Most of the articles ( $\mathrm{n}=75)$ were published between $2000-2010,16$ were published in the time frame of 25 years (1975-2000). More than half of the articles ( $n=54)$ were from the United States. New England Journal of Medicine made up almost half $(n=51)$ of the list. We found 5 authors who had up to 5 publications and rest contributed 3 or less than 3 articles.

Conclusion: This study revealed significant growth in chemotherapy literature in terms of the total number of journals, number of authors, organizations, and author collaborations.
\end{abstract}

Keywords: Bibliometrics; Chemotherapy; anticancer drugs; Impact factor; Web of Science (WOS); Scopus; Citations; Google Scholar

\section{Introduction}

Chemotherapy has evolved substantially over the past decades. Cancer is expected to increase by $50 \%$, to almost 15 million cases by 2020, hence, it is assumed that the role of chemotherapy to battle cancer will continue to grow [1-3]. There is no previous bibliometric analysis on chemotherapy in the literature, although many other bibliometric studies have been published in various specialties and subspecialties $[4,5]$. To bridge this gap, we conducted a quantitative analysis of most referenced 100 chemotherapy articles to give oncologists a brief overview of landmark chemotherapy studies.
Bibliometric analysis is a quantitative assessment of the academic quality of authors, articles, text or journals by statistical methods and this analysis has been used to estimate the impact of a written article and track the correlation amongst citations of the academic journal [2,6]. Bibliometric studies have been of great interest in providing an overview and to evaluate research and scientific activity. They do so by calculating bibliometric indicators and information about the quantity of published research in a specific field. 


\section{Cancer Therapy \& Oncology International Journal}

The role of citation frequency has long been debated, yet it remains the most commonly used tool to identify important discoveries and studies which have had a disproportionate influence in a field [7]. Citation classics is an important parameter to prioritize research funding in this era, emphasizing costeffectiveness. With limited health care resources, bibliometric studies can help guide researchers and research funding agencies towards areas where restriction or an increase in research activity is warranted. Considering the importance of chemotherapy, research in this field has been increasing, and numerous articles are published annually, giving an insight into the development of new drugs to combat cancer at all stages (Figure 1). The present bibliometric analysis provides all the relevant data representative of 100 most-cited articles on chemotherapy (Table 1a). This study will enable researchers to acquire the latest information about the amount of work being done in this area and hence provide ideas on future challenges to focus on.

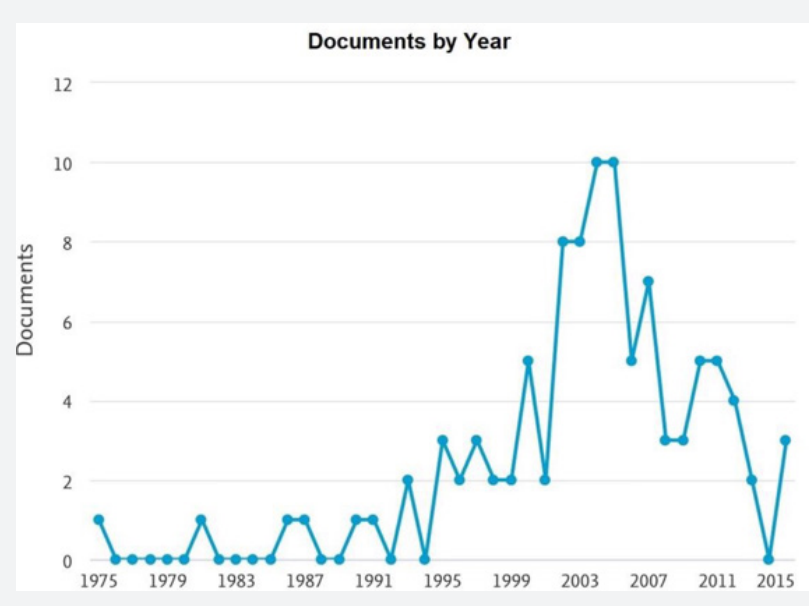

Figure 1: No. of Articles published each year from 1975-2015 among top 100 chemotherapy articles.

Table 1: Top 100 Most-cited Articles in Chemotherapy.

\begin{tabular}{|c|c|c|c|c|}
\hline No. & Title & Journal & Reference No & No. of Citations \\
\hline 1 & $\begin{array}{l}\text { Radiotherapy plus concomitant and adjuvant temozolomide for glioblas- } \\
\text { toma }\end{array}$ & NEJM & $2005 ; 352(10): 987-96$ & 8830 \\
\hline 2 & $\begin{array}{l}\text { Bevacizumab plus irinotecan, fluorouracil, and leucovorin for metastatic } \\
\text { colorectal cancer }\end{array}$ & NEJM & $2004 ; 350: 2335-2342$ & 7880 \\
\hline 3 & $\begin{array}{l}\text { Use of chemotherapy plus a monoclonal antibody against her2 for meta- } \\
\text { static breast cancer that overexpresses HER2 }\end{array}$ & NEJM & $2001 ; 344: 783-792$ & 7546 \\
\hline 4 & $\begin{array}{l}\text { EGFR mutations in lung, cancer: Correlation with clinical response to } \\
\text { gefitinib therapy }\end{array}$ & Science & $2004 ; 304(5676): 1497-500$ & 6996 \\
\hline 5 & Reporting results of cancer treatment & Cancer & $1981 ; 47(1): 207-14$ & 6743 \\
\hline 6 & $\begin{array}{l}\text { Effects of chemotherapy and hormonal therapy for early breast cancer } \\
\text { on recurrence and 15-year survival: An overview of the randomised } \\
\text { trials }\end{array}$ & Lancet & $2005 ; 365(9472): 1687-717$. & 4961 \\
\hline 7 & Erlotinib in previously treated non-small-cell lung cancer & NEJM & $2005 ; 353(2): 123-32$. & 4481 \\
\hline 8 & $\begin{array}{l}\text { Improved survival with vemurafenib in melanoma with BRAF V600E } \\
\text { mutation }\end{array}$ & NEJM & $2011 ; 364: 2507-2516$ & 4371 \\
\hline 9 & $\begin{array}{l}\text { Paclitaxel-carboplatin alone or with bevacizumab for non-small-cell lung } \\
\text { cancer }\end{array}$ & NEJM & $2006 ; 355(24): 2542-50$ & 4306 \\
\hline 10 & $\begin{array}{l}\text { A New Concept for Macromolecular Therapeutics in Cancer Chemo- } \\
\text { therapy: Mechanism of Tumoritropic Accumulation of Proteins and the } \\
\text { Antitumor Agent Smancs }\end{array}$ & Cancer Res & 1986;46(12 Pt 1):6387-92 & 4217 \\
\hline 11 & $\begin{array}{l}\text { Improvements in survival and clinical benefit with gemcitabine as first- } \\
\text { line therapy for patients with advanced pancreas cancer: A randomized } \\
\text { trial }\end{array}$ & $\begin{array}{l}\text { J Clini } \\
\text { Oncol }\end{array}$ & $1997 ; 15(6): 2403-13$ & 4163 \\
\hline 12 & $\begin{array}{l}\text { Comparison of four chemotherapy regimens for advanced non-small-cell } \\
\text { lung cancer }\end{array}$ & NEJM & $2002 ; 346(2): 92-8$. & 4050 \\
\hline
\end{tabular}




\section{Cancer Therapy \& Oncology International Journal}

\begin{tabular}{|c|c|c|c|c|}
\hline 13 & $\begin{array}{l}\text { Cetuximab monotherapy and cetuximab plus irinotecan in irinotecan- } \\
\text { refractory metastatic colorectal cancer }\end{array}$ & NEJM & $2004 ; 351(4): 337-45$. & 4013 \\
\hline 14 & $\begin{array}{l}\text { Docetaxel plus prednisone or mitoxantrone plus prednisone for ad- } \\
\text { vanced prostate cancer }\end{array}$ & NEJM & $2004 ; 351: 1502-1512$ & 3745 \\
\hline 15 & $\begin{array}{l}\text { Trastuzumab plus adjuvant chemotherapy for operable HER2-positive } \\
\text { breast cancer }\end{array}$ & NEJM & $2005 ; 353: 1673-1684$ & 3707 \\
\hline 16 & $\begin{array}{l}\text { Chop chemotherapy plus rituximab compared with chop alone in elderly } \\
\text { patients with diffuse large-B-cell lymphoma }\end{array}$ & NEJM & $2002 ; 346: 235-242$ & 3558 \\
\hline 17 & $\begin{array}{c}\text { Evaluation of a Tetrazolium-based Semiautomated Colorimetric Assay: } \\
\text { Assessment of Chemosensitivity Testing }\end{array}$ & Cancer Res & $1987 ; 47(4): 936-42$. & 3555 \\
\hline 18 & MGMT gene silencing and benefit from temozolomide in glioblastoma & NEJM & $2005 ; 352(10): 997-1003$. & 3488 \\
\hline 19 & Tamoxifen for early breast cancer: An overview of the randomised trials & Lancet & $1998 ; 351(9114): 1451-67$. & 3446 \\
\hline 20 & Multidrug resistance in cancer: Role of ATP-dependent transporters & $\begin{array}{l}\text { Nat Rev } \\
\text { Cancer }\end{array}$ & $2002 ; 2(1): 48-58$. & 3376 \\
\hline 21 & $\begin{array}{l}\text { Trastuzumab after adjuvant chemotherapy in HER2-positive breast } \\
\text { cancer }\end{array}$ & NEJM & $2005 ; 353: 1659-1672$ & 3365 \\
\hline 22 & $\begin{array}{l}\text { Efficacy and safety of imatinib mesylate in advanced gastrointestinal } \\
\text { stromal tumors }\end{array}$ & NEJM & $2002 ; 347: 472-480$ & 3176 \\
\hline 23 & $\begin{array}{c}\text { The functional assessment of cancer therapy scale: Development and } \\
\text { validation of the general measure }\end{array}$ & $\begin{array}{l}\text { J Clini } \\
\text { Oncol }\end{array}$ & $1993 ; 11(3): 570-9$. & 3160 \\
\hline 24 & $\begin{array}{l}\text { Effects of radiotherapy with concomitant and adjuvant temozolomide } \\
\text { versus radiotherapy alone on survival in glioblastoma in a randomised } \\
\text { phase III study: } 5 \text {-year analysis of the EORTC-NCIC trial }\end{array}$ & $\begin{array}{c}\text { Lancet } \\
\text { Oncol }\end{array}$ & $2009 ; 10(5): 459-66$. & 3119 \\
\hline 25 & $\begin{array}{l}\text { Leucovorin and fluorouracil with or without oxaliplatin as first-line } \\
\text { treatment in advanced colorectal cancer }\end{array}$ & $\begin{array}{l}\text { J Clini } \\
\text { Oncol }\end{array}$ & $2000 ; 18(16): 2938-47$. & 3063 \\
\hline 26 & $\begin{array}{l}\text { Gefitinib or chemotherapy for non-small-cell lung cancer with mutated } \\
\text { EGFR }\end{array}$ & NEJM & $2010 ; 362(25): 2380-8$. & 3054 \\
\hline 27 & $\begin{array}{l}\text { Trastuzumab in combination with chemotherapy versus chemotherapy } \\
\text { alone for treatment of HER2-positive advanced gastric or gastro-oe- } \\
\text { sophageal junction cancer (ToGA): A phase 3, open-label, randomised } \\
\text { controlled trial }\end{array}$ & Lancet & 2010 ;376(9742):687-97. & 2991 \\
\hline 28 & $\begin{array}{l}\text { MET amplification leads to gefitinib resistance in lung cancer by activat- } \\
\text { ing ERBB3 signaling }\end{array}$ & Science & 2007 ;316(5827):1039-43. & 2983 \\
\hline 29 & $\begin{array}{l}\text { Perioperative chemotherapy versus surgery alone for resectable gastro- } \\
\text { esophageal cancer }\end{array}$ & NEJM & $2006 ; 355: 11-20$ & 2956 \\
\hline 30 & $\begin{array}{l}\text { The glut athione s-transferase supergene family: Regulation of GST and } \\
\text { the contribution of the lsoenzymes to cancer chemoprotection and drug } \\
\text { resistance part i }\end{array}$ & $\begin{array}{l}\text { Crit Rev } \\
\text { Biochem } \\
\text { Mol Bio }\end{array}$ & 1995;30(6):445-600. & 2938 \\
\hline 31 & $\begin{array}{l}\text { Chemotherapy in non-small cell lung cancer: A meta-analysis using up- } \\
\text { dated data on individual patients from } 52 \text { randomised clinical trials }\end{array}$ & BMJ & 1995;311(7010):899-909. & 2936 \\
\hline 32 & Temsirolimus, interferon alfa, or both for advanced renal-cell carcinoma & NEJM & 2007;356(22):2271-2281 & 2726 \\
\hline 33 & $\begin{array}{l}\text { Docetaxel and estramustine compared with mitoxantrone and predni- } \\
\text { sone for advanced refractory prostate cancer }\end{array}$ & NEJM & $2004 ; 351: 1513-1520$ & 2690 \\
\hline 34 & $\begin{array}{l}\text { Mitogen-activated protein kinase pathways mediated by ERK, JNK, and } \\
\text { p38 protein kinases }\end{array}$ & Science & 2002;298(5600):1911-2. & 2685 \\
\hline 35 & $\begin{array}{l}\text { Irinotecan combined with fluorouracil compared with fluorouracil alone. } \\
\text { as first-line treatment for metastatic colorectal cancer: a multicenter } \\
\text { randomised trial }\end{array}$ & Lancet & 2000;355(9209):1041-7. & 2682 \\
\hline
\end{tabular}




\section{Cancer Therapy \& Oncology International Journal}

\begin{tabular}{|c|c|c|c|c|}
\hline 36 & $\begin{array}{l}\text { Multi-institutional randomized phase II trial of gefitinib for previously } \\
\text { treated patients with advanced non-small-cell lung cancer }\end{array}$ & $\begin{array}{l}\text { J Clini } \\
\text { Oncol }\end{array}$ & 2003;21(12):2237-46. & 2652 \\
\hline 37 & $\begin{array}{l}\text { Irinotecan plus fluorouracil and leucovorin for metastatic colorectal } \\
\text { cancer }\end{array}$ & NEJM & 2000;343(13):905-14. & 2625 \\
\hline 38 & $\begin{array}{l}\text { Erlotinib versus standard chemotherapy as first-line treatment for Euro- } \\
\text { pean patients with advanced EGFR mutation-positive non-small-cell lung } \\
\text { cancer (EURTAC): A multicentre, open-label, randomised phase } 3 \text { trial }\end{array}$ & $\begin{array}{c}\text { Lancet } \\
\text { Oncol }\end{array}$ & $2012 ; 13(3): 239-46$ & 2582 \\
\hline 39 & $\begin{array}{l}\text { Imatinib compared with interferon and low-dose cytarabine for newly } \\
\text { diagnosed chronic-phase chronic myeloid leukemia }\end{array}$ & NEJM & 2003;348(11):994-1004. & 2503 \\
\hline 40 & $\begin{array}{l}\text { The use of molecular profiling to predict survival after chemotherapy for } \\
\text { diffuse large-B-cell lymphoma }\end{array}$ & NEJM & 2002;346(25):1937-47. & 2490 \\
\hline 41 & $\begin{array}{l}\text { Cetuximab and chemotherapy as initial treatment for metastatic colorec- } \\
\text { tal cancer }\end{array}$ & NEJM & 2009;360(14):1408-17 & 2489 \\
\hline 42 & $\begin{array}{l}\text { Cyclophosphamide and cisplatin compared with paclitaxel and cisplatin } \\
\text { in patients with stage III and stage IV ovarian cancer }\end{array}$ & NEJM & 1996;334(1):1-6. & 2488 \\
\hline 43 & FOLFIRINOX versus gemcitabine for metastatic pancreatic cancer & NEJM & 2011;364(19):1817-25. & 2465 \\
\hline 44 & $\begin{array}{l}\text { Gefitinib versus cisplatin plus docetaxel in patients with non-small-cell } \\
\text { lung cancer harbouring mutations of the epidermal growth factor recep- } \\
\text { tor (WJTOG3405): an open label, randomised phase } 3 \text { trial }\end{array}$ & $\begin{array}{l}\text { Lancet } \\
\text { Oncol }\end{array}$ & 2010;11(2):121-8. & 2459 \\
\hline 45 & $\begin{array}{l}\text { Erlotinib plus gemcitabine compared with gemcitabine alone in patients } \\
\text { with advanced pancreatic cancer: A phase III trial of the National Cancer } \\
\text { Institute of Canada Clinical Trials Group }\end{array}$ & $\begin{array}{l}\text { J Clini } \\
\text { Oncol }\end{array}$ & 2007;25(15):1960-6. & 2446 \\
\hline 46 & $\begin{array}{l}\text { Ipilimumab plus dacarbazine for previously untreated metastatic mela- } \\
\text { noma }\end{array}$ & NEJM & $2011 ; 364: 2517-2526$ & 2440 \\
\hline 47 & $\begin{array}{l}\text { K-ras mutations and benefit from cetuximab in advanced colorectal } \\
\text { cancer }\end{array}$ & NEJM & 2008;359(17):1757-65. & 2419 \\
\hline 48 & Inhibition of mutated, activated BRAF in metastatic melanoma & NEJM & $2010 ; 363: 809-819$ & 2404 \\
\hline 49 & $\begin{array}{l}\text { Chemoradiotherapy after surgery compared with surgery alone for ade- } \\
\text { nocarcinoma of the stomach or gastroesophageal junction }\end{array}$ & NEJM & $2001 ; 345: 725-730$ & 2385 \\
\hline 50 & $\begin{array}{l}\text { Five-year follow-up of patients receiving imatinib for chronic myeloid } \\
\text { leukemia }\end{array}$ & NEJM & $2006 ; 355(23): 2408-17$ & 2358 \\
\hline 51 & $\begin{array}{l}\text { Multinational study of the efficacy and safety of humanized anti-HER2 } \\
\text { monoclonal antibody in women who have HER2-overexpressing } \\
\text { metastatic breast cancer that has progressed after chemotherapy for } \\
\text { metastatic disease }\end{array}$ & $\begin{array}{l}\text { J Clini } \\
\text { Oncol }\end{array}$ & 1999;17(9):2639-48. & 2290 \\
\hline 52 & $\begin{array}{l}\text { FOLFIRI followed by FOLFOX6 or the reverse sequence in advanced } \\
\text { colorectal cancer: A randomized GERCOR study }\end{array}$ & $\begin{array}{l}\text { J Clini } \\
\text { Oncol }\end{array}$ & $2004 ; 22(2): 229-37$ & 2283 \\
\hline 53 & $\begin{array}{l}\text { Paclitaxel plus bevacizumab versus paclitaxel alone for metastatic breast } \\
\text { cancer }\end{array}$ & NEJM & 2007;357(26):2666-76. & 2278 \\
\hline 54 & $\begin{array}{l}\text { A clinical staging system for multiple myeloma correlation of measured } \\
\text { myeloma cell mass with presenting clinical features, response to treat- } \\
\text { ment, and survival }\end{array}$ & Cancer & $1975 ; 36(3): 842-54$ & 2272 \\
\hline 55 & $\begin{array}{l}\text { Efficacy of Gefitinib, an Inhibitor of the Epidermal Growth Factor Recep- } \\
\text { tor Tyrosine Kinase, in Symptomatic Patients with Non-Small Cell Lung } \\
\text { Cancer: A Randomized Trial }\end{array}$ & JAMA & $2003 ; 290(16): 2149-58$ & 2262 \\
\hline 56 & $\begin{array}{l}\text { Oxaliplatin, fluorouracil, and leucovorin as adjuvant treatment for colon } \\
\text { cancer }\end{array}$ & NEJM & $2004 ; 350: 2343-2351$ & 2257 \\
\hline
\end{tabular}




\section{Cancer Therapy \& Oncology International Journal}

\begin{tabular}{|c|c|c|c|c|}
\hline 57 & $\begin{array}{l}\text { Nivolumab versus docetaxel in advanced squamous-cell non-small-cell } \\
\text { lung cancer }\end{array}$ & NEJM & $2015 ; 373: 123-135$ & 2256 \\
\hline 58 & $\begin{array}{l}\text { A prospective, randomized trial of autologous bone marrow transplanta- } \\
\text { tion and chemotherapy in multiple myeloma }\end{array}$ & NEJM & 1996;335(2):91-7. & 2247 \\
\hline 59 & $\begin{array}{l}\text { Phase III study comparing cisplatin plus gemcitabine with cisplatin plus } \\
\text { pemetrexed in chemotherapy-naive patients with advanced-stage non- } \\
\text { small-cell lung cancer }\end{array}$ & $\begin{array}{l}\text { J Clini } \\
\text { Oncol }\end{array}$ & 2008;26(21):3543-51. & 2214 \\
\hline 60 & The resurgence of platinum-based cancer chemotherapy & $\begin{array}{l}\text { Nat Rev } \\
\text { Cancer }\end{array}$ & 2007;7(8):573-84. & 2207 \\
\hline 61 & Abiraterone and increased survival in metastatic prostate cancer & NEJM & 2011;364(21):1995-2005. & 2190 \\
\hline 62 & ERBB receptors and cancer: The complexity of targeted inhibitors & $\begin{array}{l}\text { Nat Rev } \\
\text { Cancer }\end{array}$ & $2005 ; 5(5): 341-54$ & 2188 \\
\hline 63 & Lapatinib plus capecitabine for HER2-positive advanced breast cancer & NEJM & 2006; 355: 2733-2743 & 2186 \\
\hline 64 & A phase 2 study of Bortezomib in relapsed, refractory myeloma & NEJM & 2003;348(26):2609-17. & 2136 \\
\hline 65 & $\begin{array}{l}\text { Erlotinib versus chemotherapy as first-line treatment for patients with } \\
\text { advanced EGFR mutation-positive non-small-cell lung cancer (OPTIMAL, } \\
\text { CTONG-0802): a multicentre, open-label, randomised, phase } 3 \text { study }\end{array}$ & $\begin{array}{l}\text { Lancet } \\
\text { Oncol }\end{array}$ & 2011;12(8):735-42. & 2133 \\
\hline 66 & $\begin{array}{l}\text { Inhibition of poly(ADP-ribose) polymerase in tumors from BRCA muta- } \\
\text { tion carriers }\end{array}$ & NEJM & 2009;361(2):123-34 & 2122 \\
\hline 67 & $\begin{array}{l}\text { EASL clinical practice guidelines: Management of chronic hepatitis B } \\
\text { virus infection }\end{array}$ & J Hepatol & 2012;57(1):167-85. & 2104 \\
\hline 68 & Antitumor activity of thalidomide in refractory multiple myeloma & NEJM & 1999;341(21):1565-71. & 2059 \\
\hline 69 & Cellular processing of platinum anticancer drugs & $\begin{array}{l}\text { Nat Rev } \\
\text { Drug Dis- } \\
\text { cov }\end{array}$ & 2005 Apr;4(4):307-20. & 2053 \\
\hline 70 & Effects of torcetrapib in patients at high risk for coronary events & NEJM & 2007;357(21):2109-22. & 2050 \\
\hline 71 & $\begin{array}{l}\text { Nivolumab versus docetaxel in advanced nonsquamous non-small-cell } \\
\text { lung cancer }\end{array}$ & NEJM & $2015 ; 373: 1627-1639$ & 2037 \\
\hline 72 & Targeting multidrug resistance in cancer & $\begin{array}{l}\text { Nat Rev } \\
\text { Drug Dis- } \\
\text { cov }\end{array}$ & 2006;5(3):219-34. & 2016 \\
\hline 73 & Nanoparticles in cancer therapy and diagnosis & $\begin{array}{l}\text { Adv Drug } \\
\text { Deli Rev }\end{array}$ & 2002;54(5):631-51. & 1996 \\
\hline 74 & 5-Fluorouracil: Mechanisms of action and clinical strategies & $\begin{array}{l}\text { Nat Rev } \\
\text { Cancer }\end{array}$ & 2003;3(5):330-8. & 1993 \\
\hline 75 & Matrix metalloproteinase inhibitors and cancer: Trials and tribulations & Science & $2002 ; 295(5564): 2387-92$. & 1976 \\
\hline 76 & $\begin{array}{l}\text { Randomized phase III trial of pemetrexed versus docetaxel in patients } \\
\text { with non-small-cell lung cancer previously treated with chemotherapy }\end{array}$ & $\begin{array}{l}\text { J Clini } \\
\text { Oncol }\end{array}$ & 2004;22(9):1589-97. & 1967 \\
\hline 77 & $\begin{array}{l}\text { Bevacizumab in combination with oxaliplatin-based chemotherapy as } \\
\text { first-line therapy in metastatic colorectal cancer: A randomized phase III } \\
\text { study }\end{array}$ & $\begin{array}{l}\text { J Clini } \\
\text { Oncol }\end{array}$ & $2008 ; 26(12): 2013-9$. & 1944 \\
\hline 78 & $\begin{array}{l}\text { Chemotherapy added to locoregional treatment for head and neck squa- } \\
\text { mous-cell carcinoma: Three meta-analyses of updated individual data }\end{array}$ & Lancet & $1997 ; 277(5331): 1508-10$. & 1938 \\
\hline 79 & $\begin{array}{l}\text { Differential ligand activation of estrogen receptors ER } \alpha \text { and ERr } \beta \text { at AP1 } \\
\text { sites }\end{array}$ & Science & 1997;277(5331):1508-10. & 1936 \\
\hline 80 & $\begin{array}{l}\text { Combined nivolumab and ipilimumab or monotherapy in untreated } \\
\text { Melanoma }\end{array}$ & NEJM & $2015 ; 373: 23-34$ & 1918 \\
\hline 81 & $\begin{array}{l}\text { Postoperative radiotherapy in high-risk premenopausal women with } \\
\text { breast cancer who receive adjuvant chemotherapy }\end{array}$ & NEJM & 1997;337(14):949-55. & 1894 \\
\hline 82 & $\begin{array}{l}\text { Increased survival with enzalutamide in prostate cancer after chemo- } \\
\text { therapy }\end{array}$ & NEJM & $2012 ; 367(13): 1187-97$. & 1891 \\
\hline
\end{tabular}




\section{Cancer Therapy \& Oncology International Journal}

\begin{tabular}{|c|c|c|c|c|}
\hline 83 & $\begin{array}{l}\text { Polychemotherapy for early breast cancer: An overview of the ran- } \\
\text { domised trials }\end{array}$ & Lancet & 1998;352(9132):930-42. & 1871 \\
\hline 84 & $\begin{array}{l}\text { Prospective randomized trial of docetaxel versus best supportive care in } \\
\text { patients with non-small-cell lung cancer previously treated with plati- } \\
\text { num- based chemotherapy }\end{array}$ & $\begin{array}{l}\text { J Clini } \\
\text { Oncol }\end{array}$ & 2000;18(10):2095-103. & 1852 \\
\hline 85 & $\begin{array}{l}\text { Phase III study of pemetrexed in combination with cisplatin versus cis- } \\
\text { platin alone in patients with malignant pleural mesothelioma }\end{array}$ & $\begin{array}{l}\text { J Clini } \\
\text { Oncol }\end{array}$ & $2003 ; 21(14): 2636-44$. & 1846 \\
\hline 86 & $\begin{array}{c}\text { Concurrent Chemotherapy and Radiotherapy for Organ Preservation in } \\
\text { Advanced Laryngeal Cancer }\end{array}$ & NEJM & 2003; 349:2091-2098 & 1845 \\
\hline 87 & Cisplatin: Mode of cytotoxic action and molecular basis of resistance & Oncogene & $2003 ; 22(47): 7265-79$. & 1837 \\
\hline 88 & $\begin{array}{l}\text { Levamisole and fluorouracil for adjuvant therapy of resected colon } \\
\text { carcinoma }\end{array}$ & NEJM & $1990 ; 322: 352-358$ & 1827 \\
\hline 89 & $\begin{array}{l}\text { Comparison of a Standard Regimen (CHOP) with Three Intensive Chemo- } \\
\text { therapy Regimens for Advanced Non-Hodgkin's Lymphoma }\end{array}$ & NEJM & $1993 ; 328(14): 1002-6$. & 1821 \\
\hline 90 & $\begin{array}{l}\text { Gefitinib plus best supportive care in previously treated patients } \\
\text { with refractory advanced non-small-cell lung cancer: Results from a } \\
\text { randomised, placebo-controlled, multicentre study (Iressa Survival } \\
\text { Evaluation in Lung Cancer) }\end{array}$ & Lancet & $2005 ; 366(9496): 1527-37$. & 1820 \\
\hline 91 & $\begin{array}{l}\text { A randomized controlled trial of fluorouracil plus leucovorin, irinotec- } \\
\text { an, and oxaliplatin combinations in patients with previously untreated } \\
\text { metastatic colorectal cancer }\end{array}$ & $\begin{array}{l}\text { J Clini } \\
\text { Oncol }\end{array}$ & $2004 ; 22(1): 23-30$. & 1810 \\
\hline 92 & Crizotinib versus chemotherapy in advanced ALK-positive lung cancer & NEJM & $2013 ; 368(25): 2385-94$. & 1786 \\
\hline 93 & $\begin{array}{l}\text { Autologous bone marrow transplantation as compared with salvage } \\
\text { chemotherapy in relapses of chemotherapy-sensitive non-hodgkin's } \\
\text { lymphoma }\end{array}$ & NEJM & $1995 ; 333(23): 1540-5$. & 1744 \\
\hline 94 & $\begin{array}{l}\text { Results of the ATAC (Arimidex, Tamoxifen, Alone or in Combination) trial } \\
\text { after completion of } 5 \text { years' adjuvant treatment for breast cancer }\end{array}$ & Lancet & $2005 ; 365(9453): 60-2$. & 1737 \\
\hline 95 & Cancer treatment and survivorship statistics, 2012 & $\begin{array}{l}\text { CA Cancer J } \\
\text { for Clini }\end{array}$ & $2012 ; 62(4): 220-41$ & 1735 \\
\hline 96 & $\begin{array}{l}\text { Bevacizumab plus interferon alfa-2a for treatment of metastatic renal } \\
\text { cell carcinoma: a randomised, double-blind phase III trial }\end{array}$ & Lancet & $2007 ; 370(9605): 2103-11$. & 1721 \\
\hline 97 & $\begin{array}{l}\text { Induction chemotherapy plus radiation compared with surgery plus } \\
\text { radiation in patients with advanced laryngeal cancer }\end{array}$ & NEJM & $1991 ; 324(24): 1685-90$. & 1714 \\
\hline 98 & $\begin{array}{c}\text { Cisplatin-Based Adjuvant Chemotherapy in Patients with Completely } \\
\text { Resected Non-Small-Cell Lung Cancer }\end{array}$ & NEJM & $2004 ; 350(4): 351-60$ & 1702 \\
\hline 99 & $\begin{array}{l}\text { Prednisone plus cabazitaxel or mitoxantrone for metastatic castra- } \\
\text { tion-resistant prostate cancer progressing after docetaxel treatment: A } \\
\text { randomised open-label trial }\end{array}$ & Lancet & 2010;376(9747):1147-54 & 1691 \\
\hline 100 & $\begin{array}{l}\text { Increased survival in pancreatic cancer with nab-paclitaxel plus gemcit- } \\
\text { abine }\end{array}$ & NEJM & 2013; 369:1691-1703 & 1675 \\
\hline
\end{tabular}

\section{Methodology}

We performed a database search on Scopus, Web of Science (WOS) and Google Scholar, and identified the top 100 most cited articles related to chemotherapy published in professional journals from 1910 to April 2019 by using search terms "Chemotherapy" and "Anti-Cancer Drugs". The search yielded by two independent reviewers Iftikhar PM and Uddin MF showed a total number of 437,016 articles and the articles relevant to chemotherapy were shortlisted for inclusion (Table 1). These articles were ranked based on an absolute number of highest citations. Citation of Web of science was used for this analysis as WOS provides the coverage of articles from 1910 till present. The other two databases were checked for the counter reference of each article citation number and for other most-cited articles that were not available on Web of Science. No institutional or organizational review board approval was needed for our study as it was a retrospective evaluation of publicly available data. However, all the articles were published in the English language.

All the articles from various journals focusing on specialties of oncology, medicine, pathology, and pharmacology were included 


\section{Cancer Therapy \& Oncology International Journal}

to ensure that none of the articles related to chemotherapy were overlooked. There were no restrictions on study types and abstract available. After an extensive search, all the retrieved articles were sorted according to the option "times cited". We independently screened the abstracts to compile a list of the top 100 most cited chemotherapy articles. Each article is reviewed from the aspect of the number of citations, first author, year of publication, source journal, country of origin of the authors and institution [6].

The 100 articles were classified as basic science or clinical research studies and further categorized into sub-type studies like randomized controlled trials, cohort studies, cross-sectional studies, review articles, case series, case reports, and expert opinions. The h-index is defined as an index to qualify the effectiveness and citation impact of research publication of an individual [8]. $\mathrm{H}$ index was calculated to be 100 for this study. The relationship between the impact factor of a journal and the number of top 100 cited articles was analyzed using the Pearson product-moment correlation coefficient. All data is presented in the form of median and inter-quartiles (IQ). For all cases, a P-value of less than 0.05 was considered significant.

Results

Table 2: Top cited articles according to Journal and their impact factor.

\begin{tabular}{|c|c|c|}
\hline Journal's Name & Number of Articles & 2017 Impact Factor \\
\hline New England Journal of Medicine & 51 & 790238 \\
\hline Journal of Clinical Oncology & 13 & 26.303 \\
\hline Lancet & 10 & 53.254 \\
\hline Science & 5 & 37.205 \\
\hline Lancet Oncology & 4 & 33.9 \\
\hline Nature Reviews Cancer & 4 & 37.147 \\
\hline Cancer & 2 & 6.072 \\
\hline Cancer Research & 2 & 9.13 \\
\hline Nature Reviews Drug Discovery & 2 & 57 \\
\hline Advanced Drug Delivery Reviews & 1 & 15.606 \\
\hline British Medical Journal & 1 & 23.295 \\
\hline Journal of Hepatology & 1 & 7.714 \\
\hline Journal of the American Medical Association & 1 & 12.486 \\
\hline Oncogene & 1 & 47.661 \\
\hline
\end{tabular}

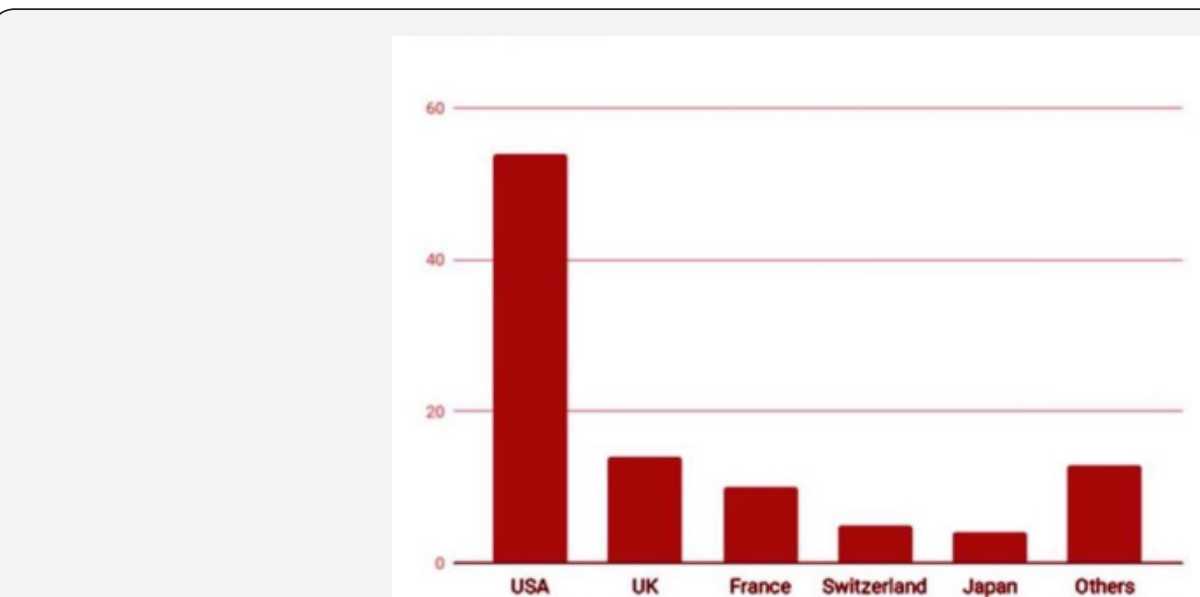

Figure 2: Contributions of countries among top 100 chemotherapy articles.

The total number of citations of these 100 most-cited articles ranged from 1675 to 8830, with a median of 2324 citations and the most referenced five articles were cited more than 6000 times by authors of fraternity [6]. The 100 most-cited 


\section{Cancer Therapy \& Oncology International Journal}

chemotherapy articles were published between 1975 and 2015 in 15 journals, with the most articles $(n=75)$ published in 10 years extending from 2000 to 2010 (Table 2). In 2003 and 2004 most referenced articles $(n=20)$ amongst the top 100 articles were published (Figure 1). Based on information about the first author we found that 100 most-cited articles originated from 13 different countries, with more than half from the USA $(n=54)$, followed by the next most popular countries of UK $(n=14)$ and France $(\mathrm{n}=10)$. Other countries of article origin included Canada, Italy, Germany, Australia, Belgium, Netherlands, Japan, and Switzerland (Figure 2).
Most referenced 100 articles were published in 15 journals and The New England Journal of Medicine ( $n=51)$, Journal of Clinical Oncology $(n=16)$ and Lancet $(n=10)$ contributed to most of the articles (Table 2). All other journals had less than 5 studies each. We found that De Bono J.S, had contributed seven articles and 3 authors (FehrenbacherL, Moore M.J, Van Custem E) had contributed four each among the top 100 articles. Other authors who contributed 3 papers each included Arriagada. R, Baselga. J, Bodrogi. I, Bryant. J, Cairncross. J.G, Cameron. D. The top 10 authors in our citation classic were De Bono J.S, Fehrenbacher. L, Moore M.J, VanCustem. E, Arriagada. R, Baselga. J, Bodrogi. I, Bryan. J, Cairncross, J.G, Cameron. D (Table 3).

Table 3: Authors with most papers among top 100 cited papers and their affiliation.

\begin{tabular}{|c|c|c|}
\hline Author Name & No. of Pages & Affiliation \\
\hline De Bono J S & 7 & Royal Marsden NHS Foundation Trust, Institute of Cancer Research, United Kingdom \\
\hline Fehrenbacher L & 4 & National Surgical Adjuvant Breast and Bowel Project, United States \\
\hline Moore M J & 4 & University Hospital Gasthuisberg, Leuven, Belgium \\
\hline Van Custem E & 4 & Instituto de Radiomedicine, chile \\
\hline Arriagada & 3 & Vall d'Hebron University Hospital, Spain \\
\hline Baselga J & 3 & Orszagos Onkologiai Intezet. Hungary \\
\hline Bodrogi I & 3 & University of pittsburgh, United States \\
\hline Bryant J & 3 & University of Calgary, Canada \\
\hline Carincross G & 3 & Western General Hospital, Edinburgh, United Kingdom \\
\hline Cameron D & 3 & City Hospital, Nottingham, United Kingdom \\
\hline Carmichael J & 3 & British Columbia Cancer agency, Canada \\
\hline Chi K N & 3 & ICRF-MRC Clinical Trail Service Unit, Oxford United Kingdom \\
\hline Collins R & 3 & Boston Dana-Farber Cancer Institute, United States \\
\hline Crowely J & 3 & Royal Marsden Hospital, United Kingdom \\
\hline Cunningham D & 3 & Johns Hopkins Kimmel Comprehensive Cancer Center United States \\
\hline Davidson N E & 3 & ICRF-MRC Clinical Trail Service Unit, Oxford United Kingdom \\
\hline Davies C & 3 & \\
\hline & & \\
\hline
\end{tabular}

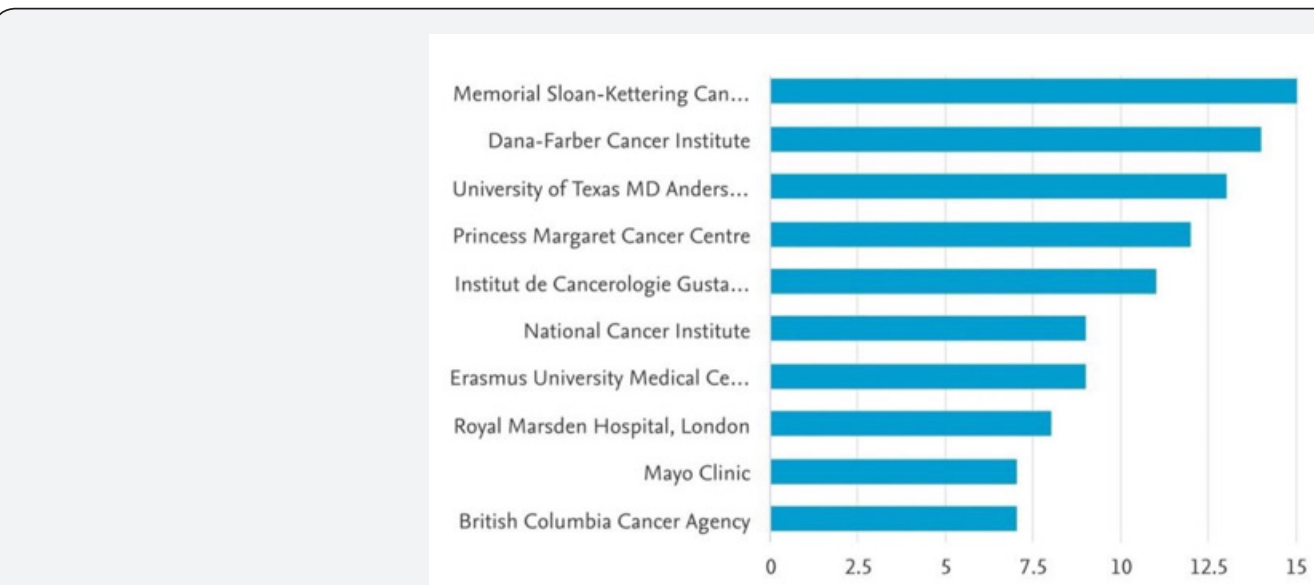

Figure 3: Contributions of individual affiliations for 100 top articles in chemotherapy. 


\section{Cancer Therapy \& Oncology International Journal}

Most articles were from US health care affiliations like Memorial Sloan Kettering Cancer Center $(n=15)$, Dana-Farber Cancer Institute $(\mathrm{n}=14)$, University of Texas MD Anderson Cancer Center $(n=12)$, while the others were from affiliations other than the USA like Princess Margaret Cancer Centre $(n=12)$, Institute de Cancerologie Gustave Roussy $(n=11)$ and the other affiliations of various countries contributed less than 10 publications (Figure 3).

Most of the research in chemotherapy was clinical research $(\mathrm{n}=74)$, while a few encompassed basic sciences and biochemical research $(n=19)$ and others $(n=7)$. Most of the articles were original articles $(n=88)$, followed by review articles $(n=11)$. The subtypes of these articles included prospective cohort, case reports, case series, cross-sectional studies, randomized controlled trials, animal studies, biochemical and in vitro studies. Among these 100 articles, a quarter of articles for chemotherapy were focused on lung cancer $(n=23)$ followed by breast cancer $(n=13)$ and colon cancer $(n=12)$. The rest of the articles focused on other systems and were related to drug mechanics, drug resistance and treatment assessment. Within the list, we found a statistically significant correlation between the number of top-cited articles and the journal impact factor $(\mathrm{P}<0.005)$ and the impact factor (IF) of journals ranged from 8.4 to 79.23. All the data have been tabulated to enhance understanding of the observations made in this study.

\section{Discussion}

Cancer is an international scourge and physicians across the world are discovering various neoplastic diseases in different parts of the world. At the same time in recent years, substantial effort has been made to search for better, more selective and effective drugs that could be used in the management of many different forms of neoplastic diseases at all stages. Chemotherapy, in combination with radiotherapy and surgery, is being incessantly studied and the clinical assessment of anticancer drugs by various controlled trials has been on the rise and has improved $[9,10]$.

This citation classics allowed us to uncover historical patterns and trends in research which has impacted major change worldwide over the years $[11,12]$. Moreover, understanding the features inherent to frequently cited work would help young researchers to publish more effectively [13-15]. In recent years, many studies have provided insight into the citation frequency of the most-cited articles published in many journals and therefore, analyzing the frequency of article citations in chemotherapy, which has seen great advances and changed the world's perspective towards cancer is necessary [16]. Citation analysis of articles plays a major role and is important in specific fields for both authors and journals. Journals use it to attract better articles, while it provides researchers with some related current information about diagnosis and therapy in their research areas, which should help them produce better work.
The number of articles labeled as "most-cited" or "top-cited" in various medical fields is increasing, but to date, there has been no bibliometric analysis of articles on chemotherapy. According to recent data, global cancer rates are estimated to increase by $50 \%$ to about 50 million cases by 2020 [1,15]. In our study 75 of the top 100 , highly cited chemotherapy papers were published during 2000-2010. In contrast to bibliometrics published in orthopedics, neurosurgery and many other fields have reported their peak period for top-cited articles from 1965 to 1980 [17].

This suggests that the field of oncology is evolving rapidly and is in sync with chemotherapy as the patient treatment approach has become more scientific with the introduction of various studies and clinical trials on a wide basis all over the world. These clinical trials help in comparing new treatments to standard treatments and it plays a pivotal role in better understanding of risks and benefits of treatment $[6,18]$. Our findings of most cited published articles contraindicate the previously published hypothesis $[12,16]$ that the article's true value cannot be judged correctly until at least 3 decades after the publication. For our chemotherapy bibliometric, the peak period of 2000-2014 is not surprising considering that evolution in technology which has resulted in novel chemotherapies targeting cancer is relatively new $[17,19]$.

When considering the timeline for bibliometrics, two important factors need to be considered. Firstly, according to obliteration by incorporation phenomenon which states that landmark articles are sometimes cited rarely because the information they provide becomes so widely used and embedded in the daily practice of each clinician, that researchers do not feel the need to cite that study [19]. Secondly, the inherent bias of bibliometrics against recent papers might lead to some extremely important papers not being included in such an analysis as it takes time to accumulate citations $[14,20]$. We further observed that the majority $(n=76)$ of the top-cited chemotherapy articles were published in high impact factor journals such as The New England Journal of Medicine ( $n=51)$, Journal of Clinical Oncology $(\mathrm{n}=16)$ and Lancet $(\mathrm{n}=10)$.

It shows that researchers tend to publish important studies about oncology and chemotherapy in influential journals, the other journals contributed less than 5 articles each. It is interesting to note that most of the top-cited articles were published in general medicine journals, this can be explained by a concept proposed by Brookes called Bradford's law, that most researchers get their citations from a few specific core journals and hence when authors decide to deviate from these journals, the impact of their article is reduced and thus most researchers try to stay loyal to those few famous journals $[15,21]$. Most researchers try to publish their articles in standard journals having higher impact factors despite variation in the field of interest. We found that the majority of the topcited chemotherapy articles focused on chemotherapy drugs 
targeting cancers like lung cancer $(n=23)$, breast cancer $(n=13)$, colon cancer ( $\mathrm{n}=12$ ) (Figure 4).

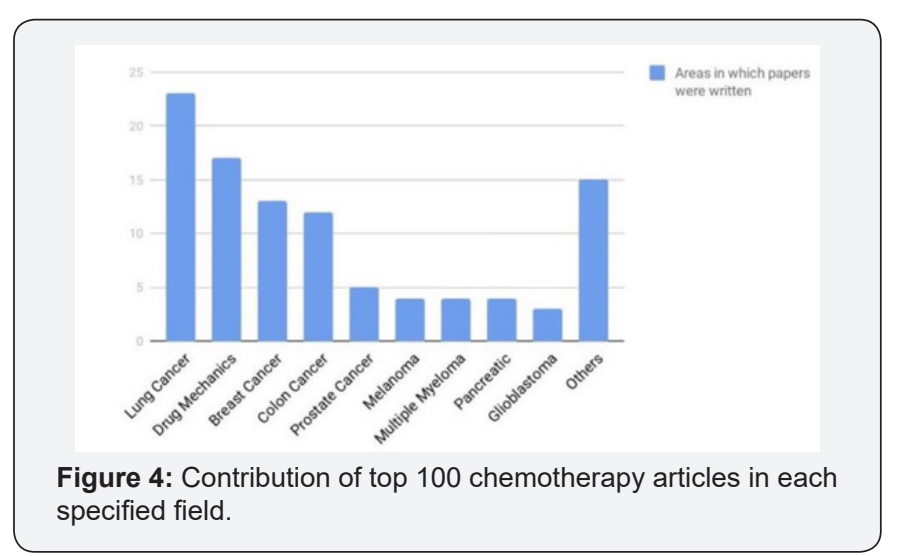

Such trends in major articles from our top 100 cited articles in the field of lung, breast. and colon cancer is not surprising as these malignancies are on the rise and are amongst the overall leading causes of mortality and morbidity. This provides vital information regarding major chemotherapy research in a field and it will help not only editors and stakeholders in selecting and judging future scientific work but also young scientists to do research effectively. Moreover, our study found that most articles $(n=88)$ were original and a few $(n=12)$ were review articles. It is important to consider that scientists who frequently produce high-quality work have a higher chance of academic promotion, and editors are more likely to accept their work and invite them to review articles [10].

Considering the burden of cancer is projected to rise, future bibliometric analyses may identify more papers on lung, breast, colon cancer and other topics such as innovations in the treatment of cancer through chemotherapies, strategies to provide remission of cancer in earlier stages, development of novel drugs which has no drug resistance potential. Despite all the advances in identifying appropriate drugs, a treatment which is selective in its attack on malignant cells exists, and only a limited percentage of patients with certain types of neoplastic disease benefit from chemotherapy. But on the other hand, the number of cancer patients to whom chemotherapy brings objective effect, including partial and complete remission of tumors, increases comparatively slowly.

This improvement is brought about by painstaking rigorous research into drug improvement, development of newer drugs with more efficacy, assessment of the treatment, development of drugs with fewer side effects, novel approaches to avoid drug resistance and methods of administration [9]. By international co-operation in the search for new drugs, and in their experimental screening and subsequent clinical trials, progress in the field could be sped up. To enhance cancer survivorship, we need collaboration among policymakers, researchers, and healthcare organizations for prevention, early detection and better prognosis [22].

\section{Limitations}

The Bibliometric analysis involves older published articles, while recently published high-quality studies would be ignored, a drawback which is related to the effect of the number of times cited. The value of contributions and progress in a field cannot be identified only by the number of citations. Therefore, having a lower citation frequency with good quality might have been missed. Lastly, the language of publication plays a major role, with a bias towards articles published in English language journals and from the developed world.

\section{Conclusion}

This bibliometric study provides a qualitative and quantitative evaluation of the most referenced chemotherapy articles in the literature. It also provides a detailed intuition into academic achievements, historical perspective that shaped the breadth of chemotherapy to serves as a guide for the scientific progress.

\section{Authorship statement}

Mohammad Faisal Uddin and Pulwasha Maria Iftikhar designed the study. All the authors performed the study, contributed to data extraction, literature review, analyzed the data, and wrote the paper.

\section{Financial disclosure statement}

This manuscript is original research, has not been previously published and has not been submitted for publication elsewhere while under consideration. Authors declare no conflict of interest with this manuscript. The authors have no relevant affiliations or financial involvement with any organization or entity with a financial interest in or financial conflict with the subject matter or materials discussed in the manuscript. This includes employment, consultancies, honoraria, stock ownership or options, expert testimony, grants or patents received or pending, or royalties.

\section{References}

1. Loomes DE, van Zanten SV (2013) Bibliometrics of the top 100 clinical articles in digestive disease. Gastroenterology 144: 673-676.

2. Hennessey K, Afshar K, Macneily AE (2009) The top 100 cited articles in urology. Can Urol Assoc J 3: 293-302.

3. Shuaib W, Acevedo JN, Khan MS, Santiago LJ, Gaeta TJ (2015) The top 100 cited articles published in emergency medicine journals. Am J Emerg Med 33: 1066-1071.

4. Ayers D (1972) Bioscientific Terminology Words from Latin and Greek Stems. The University of Arizona Press, US.

5. Pagni M, Khan NR, Cohen HL, Choudhri AF (2014) Highly cited works in radiology: the top 100 cited articles in radiologic journals. Acad Radiol 21: 1056-1066.

6. Iftikhar P M, Ali F, Faisaluddin M (2019) A bibliometric analysis of the top 30 most-cited articles in gestational diabetes mellitus literature (1946-2019). Cureus 11(2): e4131. 


\section{Cancer Therapy \& Oncology International Journal}

7. Moed HF (2002) The impact-factors debate: the ISI's uses and limits. Nature 415: 731-732.

8. Bornmann L, Daniel H (2008) The state of $h$ index research. Is the $h$ index the ideal way to measure research performance? EMBO reports 10(1): 2-6.

9. Sun W, Gu Z (2015) Engineering DNA scaffolds for delivery of anticancer therapeutics. Biomater Sci 3: 1018-1024.

10. Sporn MB (1996) The war on cancer. Lancet 347: 1377-1381.

11. Aghajanian C, Blank SV, Goff BA, Judson PL, Teneriello MG, et al. (2012) OCEANS: a randomized, double-blind, placebo-controlled phase II trial of chemotherapy with or without bevacizumab in patients with platinum-sensitive recurrent epithelial ovarian, primary peritoneal, or fallopian tube cancer. J Clin Oncol 30: 2039-2045.

12. Stossel TP (1987) Volume: papers and academic promotion. Ann Intern Med 106: 146-149.

13. Yong Hak J (2013) Web of Science. Thomas Reuters, India.

14. Callaham M, Wears RL, Weber E (2002) Journal prestige, publication bias, and other characteristics associated with citation of published studies in peer-reviewed journals. JAMA 287: 2847-2850.
15. Albert DM (1988) Analysis of the Archives' most frequently cited articles. Arch Ophthalmol 106: 465-470.

16. Lefaivre KA, Guy P, O Brien PJ, Blachut PA, Shadgan B, et al. (2010) Leading 20 at 20: top cited articles and authors in the Journal of Orthopaedic Trauma, 1987-2007. J Orthop Trauma 24: 53-58.

17. Moed HF (2009) New developments in the use of citation analysis in research evaluation. Arch Immunol Ther Exp (Warsz) 57: 13-18.

18. Sunil Rajpal, Abhishek Kumar, William Joe (2014) Economic burden of cancer in India: Evidence from cross-sectional nationally representative household survey PLOS One 26: 13(2).

19. Sztompka P (1991) Society in Action: The Theory of Social Becoming The University of Chicago Press, US.

20. Seglen PO (1998) Citation rates and journal impact factors are not suitable for evaluation of research. Acta Orthop Scand 69: 224-229.

21. Brookes BC (1969) Bradford's law and the bibliography of science. Nature 224: 953-956

22. The American Cancer Society medical and editorial content team (2019) Evaluation of cancer treatments: Chemotherapy.

\section{Your next submission with Juniper Publishers will reach you the below assets}

- Quality Editorial service

- Swift Peer Review

- Reprints availability

- E-prints Service

- Manuscript Podcast for convenient understanding

- Global attainment for your research

- Manuscript accessibility in different formats

( Pdf, E-pub, Full Text, Audio)

- Unceasing customer service

Track the below URL for one-step submission https://juniperpublishers.com/online-submission.php 